\title{
AN IRRIGATION CANAL AS A LOTIC MESOCOSM: EXAMINING THE RELATIONSHIP BETWEEN MACROINVERTEBRATE BENTHOS AND DRIFT
}

\author{
Peter Koetsier1,2 and Luana M. M. McCauley ${ }^{1}$
}

\begin{abstract}
We explored the notion that small canals could be good experimental proxies of streams by documenting physiochemical parameters and macroinvertebrate community development in an aridland irrigation canal. Further, we tested the production-compensation hypothesis between benthic invertebrates and invertebrates in the water column (drift). If the hypothesis held, invertebrates in the drift would be low until the benthic carrying capacity was reached; then organisms in the drift would increase as individuals avoided overcrowded conditions in the substrate. In a small, naturalized freshwater canal, we sampled macroinvertebrates in the substrate and those in the drift once every 2 weeks over 170 days (May-October). We placed macroinvertebrates into functional feeding groups (FFG) and examined these groups along with total density and taxa richness. We found no density-dependent relationship either in FFG or total density between the benthos and invertebrates in the drift. Our negative results might indicate that the stream benthos did not reach carrying capacity (partially affected by adult emergence in the autumn), the invertebrate dynamics in the canal did not adequately represent those occurring in a natural stream, or the duration of our study was too short. However, the invertebrate community in the canal did follow community buildup patterns for small streams reported in the literature, and it also resembled the community in a nearby natural stream. We suggest that naturalized canals could be used as "mesocosms," mimicking small natural streams, in which highly manipulative experiments could be conducted. In addition, the effects of temporary and permanent canals across the arid western landscape have been understudied and represent a new area of ecological research.
\end{abstract}

RESUMEN.-Exploramos la idea de que canales pequeños podrían ser buenas aproximaciones experimentales de los arroyos, documentando los parámetros fisicoquímicos y el desarrollo de la comunidad de macro-invertebrados en un canal de riego en tierra árida. Además, probamos la hipótesis de producción-compensación entre los invertebrados bentónicos y aquellos que se encuentran en la columna de agua (a la deriva). Si la hipótesis es apoyada, el número de invertebrados a la deriva sería bajo hasta que se alcanzara la capacidad de carga bentónica. Entonces los organismos a la deriva podrían aumentar en número, ya que los individuos evitarían condiciones de hacinamiento en el sustrato. En un canal naturalizado de agua dulce pequeño, tomamos muestras de macro-invertebrados en el sustrato y de aquellos a la deriva una vez cada 2 semanas durante 170 días (de mayo a octubre). Colocamos macro-invertebrados en grupos de alimentación funcional (FFG) y examinamos estos grupos junto con la densidad total y la riqueza de taxa. No encontramos ninguna relación denso-dependiente entre los organismos bentónicos y aquellos a la deriva, ya sea en FFG o en las densidades totales. Nuestros resultados negativos podrían deberse a: los bentos de los arroyos no alcanzaron la capacidad de carga (en parte afectados por la emergencia de individuos adultos durante el otoño), la dinámica de los invertebrados en el canal no representa adecuadamente a aquellos en un arroyo natural, o la duración de nuestro estudio fue muy corta. Sin embargo, el canal siguió los patrones de desarrollo de la comunidad en los pequeños arroyos descritos en la literatura, y la comunidad de invertebrados se asemejaba a la de un arroyo natural cercano. Sugerimos que los canales naturalizados puedan ser utilizados como "mesocosmos," que imiten pequeños arroyos naturales en los que puedan llevarse a cabo experimentos altamente manipulables. Además, los efectos de los canales temporales y permanentes en todo el paisaje árido del oeste no han sido ampliamente estudiados y representan una nueva zona de investigación ecológica.

Stream drift, the downstream transport of organisms by the water's current, has intrigued stream ecologists since Denby (1944) first considered drifting organisms part of the normal process in streams, despite lack of abnormal flows. Drift is a primary means by which macroinvertebrates disperse and colonize which suggests a behavioral element
(Müller 1974). As a result, Waters (1972) proposed 3 categories of drift: catastrophic (passive) drift resulting from sudden increases in current velocity (Imbert and Perry 2000, Gibbins et al. 2007), constant drift in which low numbers of most species occur continuously in the current (Waters 1965), and behavioral (active) drift that may be the end product of

\footnotetext{
${ }^{1}$ Department of Biological Sciences, Boise State University, 1910 University Dr. Boise, ID 83725-1515.

2E-mail: pkoet@boisestate.edu
} 
invertebrates avoiding competitors, predators, or overcrowded benthic conditions (Kohler 1985, Brittain and Eikeland 1988). Further, Waters (1972) and Müller (1974) classified 2 trends in diel drift. The first is the alternans pattern (characterized by a minor peak shortly after sunset and a major peak prior to sunrise), and the second is the bigeminus pattern (a large peak after sunset and a smaller peak prior to sunrise). Although benthic invertebrates can colonize new habitat by vertical migration from the hyporeic zone or by upstream movement as aquatic larvae or aerial adults, drift is considered the most important process for colonization and dispersal (Williams 1977, Mackay 1992).

Despite the intense interest in stream drift over the last half century, the relationship between benthic densities and drift remains unclear (Waters 2000, Allan and Castillo 2007). In studying the behavioral mechanisms that induced benthic invertebrates to enter the water column, Waters $(1961,1965)$ suggested that drift may be density dependent and could be viewed as a "release valve" for excess benthic production above substrate carrying capacity. This production-compensation hypothesis predicts that in newly available habitats, benthic numbers will increase as invertebrates colonize the area. As density increases, little or no drift will occur until a level is reached (i.e., carrying capacity of the substrate) where biotic regulatory mechanisms (aggression, competition, or lack of food/space resources) begin to occur. At this time, the hypothesis further predicts that benthic density will remain constant but drift density will increase as individuals leave or are forced out. Indeed, after applying an insecticide to 17 streams, Dimond (1967) followed benthic invertebrate recovery of streams for 7 years. He found that only after the benthos reached a "recovered" density (compared to pre-insecticide levels) did drift become significant. Others, too, have suggested that drift may be a densitydependent mechanism of the benthos (Kohler 1985, Anholt 1995, Turner and Williams 2000).

Alternatively, some investigators found no density-dependent relationship between benthic and drift densities (Hildebrand 1974, Humphries 2002). In these studies, drift density was directly proportional to benthic density. To escape visually oriented predators, invertebrates feed at night, moving to the tops of algal-covered cobbles to do so. This increases their risk of being swept away by the current (Allan 1978). Consequently, drift appears to be a function of the probability of dislodgement from the substrate, which would not be affected by density (Hildebrand 1974, Humphries 2002).

In most drift/benthos studies, researchers have either focused on a few species in a natural stream (i.e., Turner and Williams 2000) or studied several species isolated in artificial streams (i.e., Hildebrand 1974). Few have studied benthic community build-up and subsequent drift in newly formed streams (but see Williams and Hynes 1977, Gore 1979), yet these types of systems seem best suited for examining possible connections between the benthic community and its subsequent drift. Ideally, researchers need to know the "fill history" of a stream-when water begins to flowso that the benthic community buildup can be sampled and tracked. However, it is difficult to find newly created stream channels or areas of stream bottom that are initially devoid of macroinvertebrates. One possible system might be agricultural canals and ditches. Some canals can resemble small stream ecosystems, complete with sand/pebble/cobble substrate, small pools, and riparian/emergent vegetation (Herzon and Helenius 2008). Ditches can provide habitat for aquatic invertebrates not found in larger, perennial bodies of water (Williams et al. 2004) and may increase taxonomic invertebrate richness in stream networks by increasing habitat heterogeneity (Simon and Travis 2011).

In the western USA, canals and ditches used for irrigating cropland may increase the amount of aquatic habitat in an arid environment. In Idaho alone, there are approximately $24,000 \mathrm{~km}$ of canals along the Snake River (Fiege 1999). Irrigation canals are inundated in late spring and remain filled throughout the summer and early autumn (i.e., during the growing season). In mid-autumn, water is cut off, allowing the canals and ditches to dry and remain so during the winter and early spring months (Fiege 1999).

For several reasons, western irrigation canals have potential to elucidate the relationship between macroinvertebrate benthic and drift densities. These systems may resemble small natural streams (Simon and Travis 2011, Leslie et al. 2012); they are accessible and easily sampled, may have fairly low species richness (usually species prone to drift), and have 


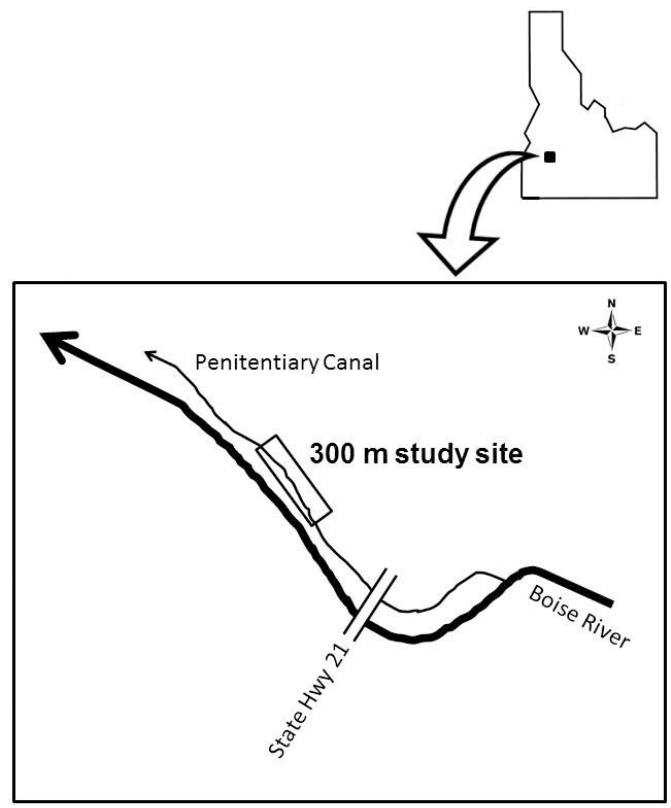

Fig. 1. Location schematics of the study site in relation to Penitentiary Canal and the Boise River, Idaho.

stable and constant discharge throughout the irrigation season. Their "fill history" is obtainable either from irrigation districts or by direct observation. Finally, the long dry period during the winter removes the confounding effect of colonization from hyporeos migration or by upstream movement of other benthic invertebrates. This essentially makes the canal a newly formed "temporary stream" with no previous occupants: all benthic invertebrates collected originated from upstream sources.

In view of this, one objective of this study was to examine the short-term relationship between benthic macroinvertebrates and drift, focusing on the total community making up the benthos and drift. A second objective was to document physiochemical pararmeters, algal/biofilm accumulation, and benthic invertebrate community development in a small irrigation canal. Most research involving agricultural canals and ditches focuses on sediment erosion and transport or on fertilizer and pesticide/herbicide movement (and their effect on water quality) from agricultural lands to permanent water bodies via canals (Herzon and Helenius 2008, Roach et al. 2008, Leslie et al. 2012). Irrigation canals and ditches have the potential to become "natural" mesocosms in which to study benthic community development in lotic systems. In a canal, we collected macroinvertebrates from the substrate and the water column every 2 weeks over the course of irrigation season (May-October). We compared density, species number, and functional feeding groups between benthos and drift; we found no significant relationship between these 2 portions of the macroinvertebrate community.

\section{STUdy SITE}

The study site was located in southwestern Idaho, $3 \mathrm{~km}$ southwest from the city of Boise. This portion of Idaho is arid public land with an annual precipitation ranging from 17 to 28 $\mathrm{cm}$ and an elevation of $830 \mathrm{~m}$ asl. This study was conducted in the Penitentiary Canal, a lateral irrigation canal located along the outer edge of the riparian area of the mainstem Boise River; the canal runs parallel to the river (Fig. 1). Riparian area along the river has been set aside as critical wintering habitat for the Bald Eagle (Haliaeetus leucocephalus), hence at the time of this study no development or agriculture had occurred along this section. The streamside vegetation was composed of forbes, grasses, and occasional sagebrush (Artemisia tridentata). However, irrigated pasture did occur 5-6 km downstream, where the terrain flattened out and several irrigation ditches branched off from the lateral. Water flowed through the Penitentiary Canal during the region's growing season: May-October. When inundated, the canal had an average discharge of $0.16 \mathrm{~m}^{3} \cdot \mathrm{s}^{-1}$ (SD 0.03, $n=10$; Fig. 2A), a mean bank full depth of $44.6 \mathrm{~cm}$ (SD 6.1, $n=10$ ), and an average width of 2.6 $\mathrm{m}(\mathrm{SD} 6.5, n=10)$. The substrate in Penitentiary Canal was a mixture of sand, large gravel, and cobbles (average long axis $9.3 \mathrm{~cm}$ ), which extended up over the banks to prevent erosion. A 300-m section $\left(43^{\circ} 32^{\prime} 39.55^{\prime \prime},-116^{\circ} 05^{\prime} 49.56^{\prime \prime}\right)$ was sampled approximately $0.8 \mathrm{~km}$ downstream from where the Penitentiary Canal branched off from the river. A graded screen at the divergence point of the canal from the river prevented woody debris and fish from entering.

\section{Methods}

Drifting and benthic macroinvertebrates were sampled approximately once every 2 weeks from May to October. Drift was collected 3 times per 24-h cycle: $1 \mathrm{~h}$ before sunrise (AM), at noon (NOON), and again $1 \mathrm{~h}$ 


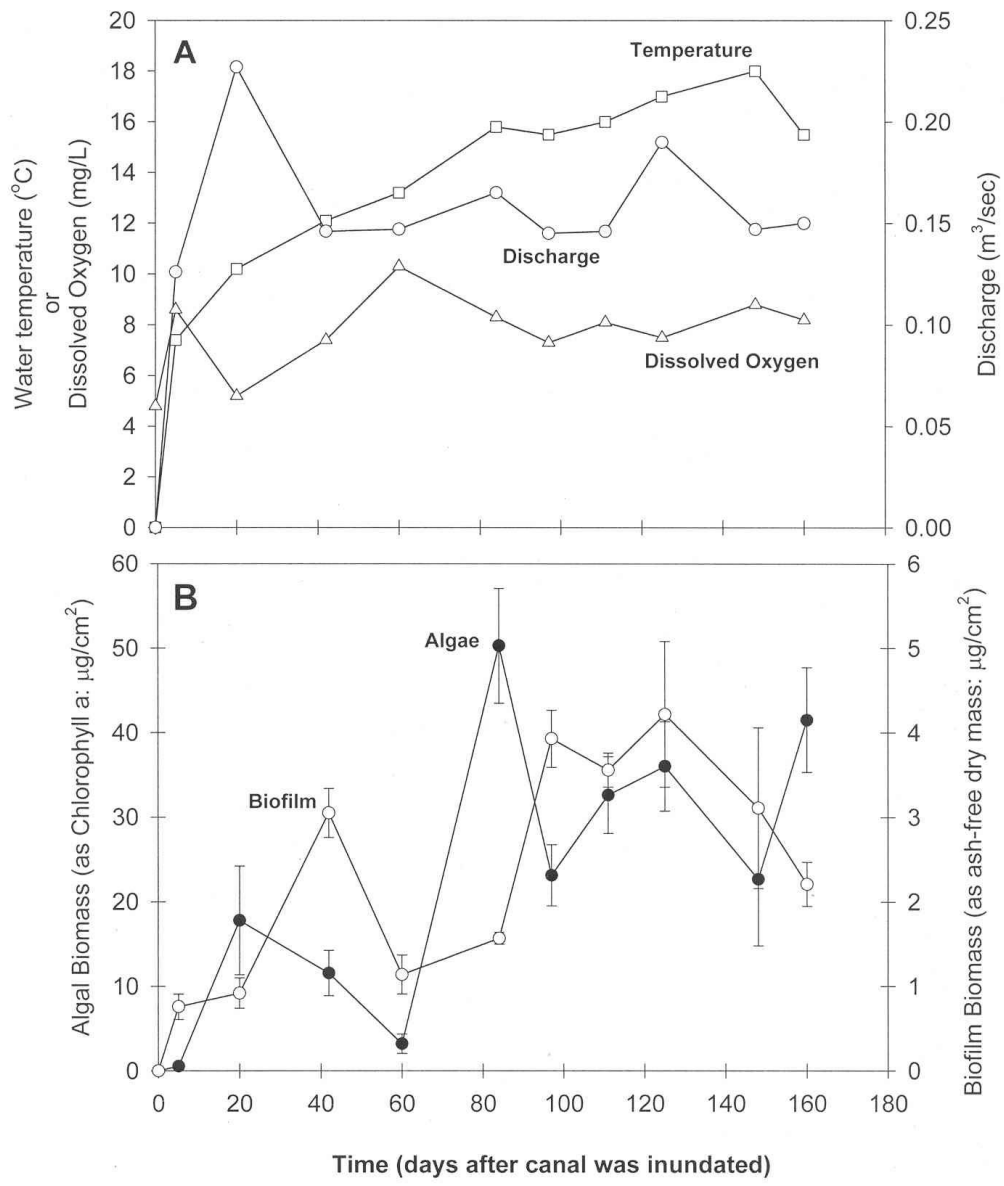

Fig. 2. (A) Water temperature, discharge, and dissolved oxygen measured in the canal. (B) Mean $( \pm 1$ SE, $n=6)$ algal biomass (as chlorophyll $a$ ) and biofilm biomass collected during the same period. The canal was filled on 30 April (day 0 ) and emptied on 15 October (day 170).

after sunset $(\mathrm{PM})$. This regime allowed us to sample the bigeminus/alteran peaks (AM, PM) and constant drift (NOON) (Waters 1972). At each sampling time, 5 drift nets were set, side by side, perpendicular to the flow across the canal. These nets were located at the upstream end of the site in each sampling time. Each net had a mouth area of $150 \mathrm{~cm}^{2}$, a total net length of $100 \mathrm{~cm}$, and was made of $260-\mu \mathrm{m}$ Nitex mesh. Throughout the drift sampling, water velocity at each net's mouth was checked every $10 \mathrm{~min}$. A decrease in water velocity from the initial measurement indicated net clogging and the net was removed (mean sampling time $32 \mathrm{~min}$ ). Upon net removal, the collected material was washed into containers, preserved in $7 \%$ buffered formalin, and taken back to the laboratory for sorting, identification, and enumeration. Five benthic samples were collected using a standard Surber sampler $\left(0.093 \mathrm{~m}^{2}, 600 \mu \mathrm{m}\right.$ Nitex mesh) in conjunction with the noon drift collections. Each benthic sample was randomly located $>10 \mathrm{~m}$ downstream of the drift nets. Benthic samples were collected, washed into containers, preserved in $7 \%$ buffered formalin, and transported back to the laboratory. In the laboratory, a dissecting microscope was used to aid in the sorting of macroinvertebrates from detritus. Macroinvertebrates, identified to species when possible, were placed into functional feeding groups (Pennak 1989, Barbour et al. 1999, Merritt et al. 2008), oven-dried for $48 \mathrm{~h}$ at 100 ${ }^{\circ} \mathrm{C}$, and weighed to estimate biomass. At this time richness (number of taxa) was calculated for each macroinvertebrate sample. 
To determine if the irrigation canal adequately mimicked a small natural stream, we measured selected physiochemical parameters. At noon, in conjunction with the drift/ benthic sampling, we measured dissolved oxygen, conductivity, and stream temperature; all at a single point in the thalwag, downstream from the drift nets with a handheld, multiprobe meter (YSI Model 85). With these measurements, canal discharge was also estimated by dividing the cross-section of the canal channel into 15 segments. A single velocity measurement in each segment (measured 6/10 depth from the water's surface with a flow meter) was measured. Discharge was calculated by summing the volume of water flowing through each segment (Gordon et al. 2004).

To ascertain if an adequate basal food resource for macroinvertebrates existed in the canal, we sampled periphyton to estimate algal and biofilm biomass. In the canal at noon, we sampled periphyton by taking a slurry sample from each of 5 randomly selected stream cobbles, downstream of the nets (Koetsier 2005). To collect the slurry samples, we used a small plastic tube fitted with a neoprene gasket at one end, which provided a watertight seal when placed on the stone. Filling the tube with $5 \mathrm{~mL}$ of water, we used a small brush to gently scrub the area of the stone enclosed by the tube. The resulting slurry was drawn out with a syringe. Once taken, slurry samples were placed on ice and transported back to the laboratory for immediate processing. In the laboratory, algal biomass was estimated by measuring the absorbance of chlorophyll $a$ from the slurry samples. Following methods of Holm-Hansen (1978) and Hansson (1988), each sample was vacuum filtered through a Whatman GF/F glass filter (pore size: $0.45 \mathrm{~mm}$ ). Chlorophyll $a$ was extracted by immersing the filters in $10 \mathrm{~mL}$ of absolute methanol and then refrigerating the sample at $4{ }^{\circ} \mathrm{C}$ for $3 \mathrm{~h}$. After centrifuging, chlorophyll $a$ concentrations were measured with a spectrophotometer; these values were corrected for phaeophytin. To determine biofilm biomass, the extract was dried for 4 days at $30{ }^{\circ} \mathrm{C}$, weighed to obtain dry mass, and combusted in a muffle furnace at $600{ }^{\circ} \mathrm{C}$ for $4 \mathrm{~h}$. The samples were rehydrated and reweighed to obtain ashed mass. Ash-free dry mass (AFDM) of each slurry sample was calculated by subtracting the ashed mass from the dry mass (Steinman et al. 2006).

We used a one-way repeated-measures analysis of variance (with collection time as the independent variable, date as the repeated measure, and drift density as the response variable) to ascertain if drifting macroinvertebrate density differed among the collection times on each date. Our data met the assumptions of normality and constant variance, so data transformation was not necessary for these statistical tests. To determine if there was a density-dependent relationship between benthic invertebrates and invertebrates found in the drift, we regressed total drift density as a function of benthic density. If a densitydependent relationship exists, then a curvilinear response (i.e., J-shaped curve) between drift and benthic densities would be expected: drift and benthic densities would be proportional until a threshold was reached, then benthic density would remain constant while drift density would continue to increase.

\section{RESULTS}

Physical and biotic variables measured in the canal after inundation, which may directly affect the macroinvertebrate community, were similar to those of 2 small natural streams in the same drainage basin (Indian and Mason Creeks, $43^{\circ} 36^{\prime} \mathrm{N}, 116^{\circ} 25^{\prime} \mathrm{W}$; Koetsier 2002). Once the canal was completely inundated, specific conductance $\left(\bar{x}=50.92 \mathrm{mS} \cdot \mathrm{m}^{-1}\right.$, SE 2.6) and dissolved oxygen $\left(\bar{x}=7.6 \mathrm{mg} \cdot \mathrm{L}^{-1}\right.$, SE 0.53 ) became stable and remained fairly consistent throughout the sampling period (Fig. 2A). Water temperature (overall $\bar{x}=13.9$ ${ }^{\circ} \mathrm{C}$, SE 1.03) rose slowly and steadily throughout the study, then dipped slightly before the canal was drained (Fig. 2A). Both algal and biofilm biomass were highly variable in the first 84 days after canal inundation but then displayed a similar, tandem pattern until the canal emptied in October (Fig. 2B).

Total densities and taxon richness of organisms in the drift and from the benthos had the same general pattern throughout the study period (Fig. 3). Taxon numbers in both drift and benthos rose steadily from Day 0 to Day 60, then stabilized over the rest of the study. Organisms both in the drift and in the benthos had a peak in density early in community development (day 42: mean drift $=74 \mathrm{~m}^{-3}$, mean benthos $=$ 

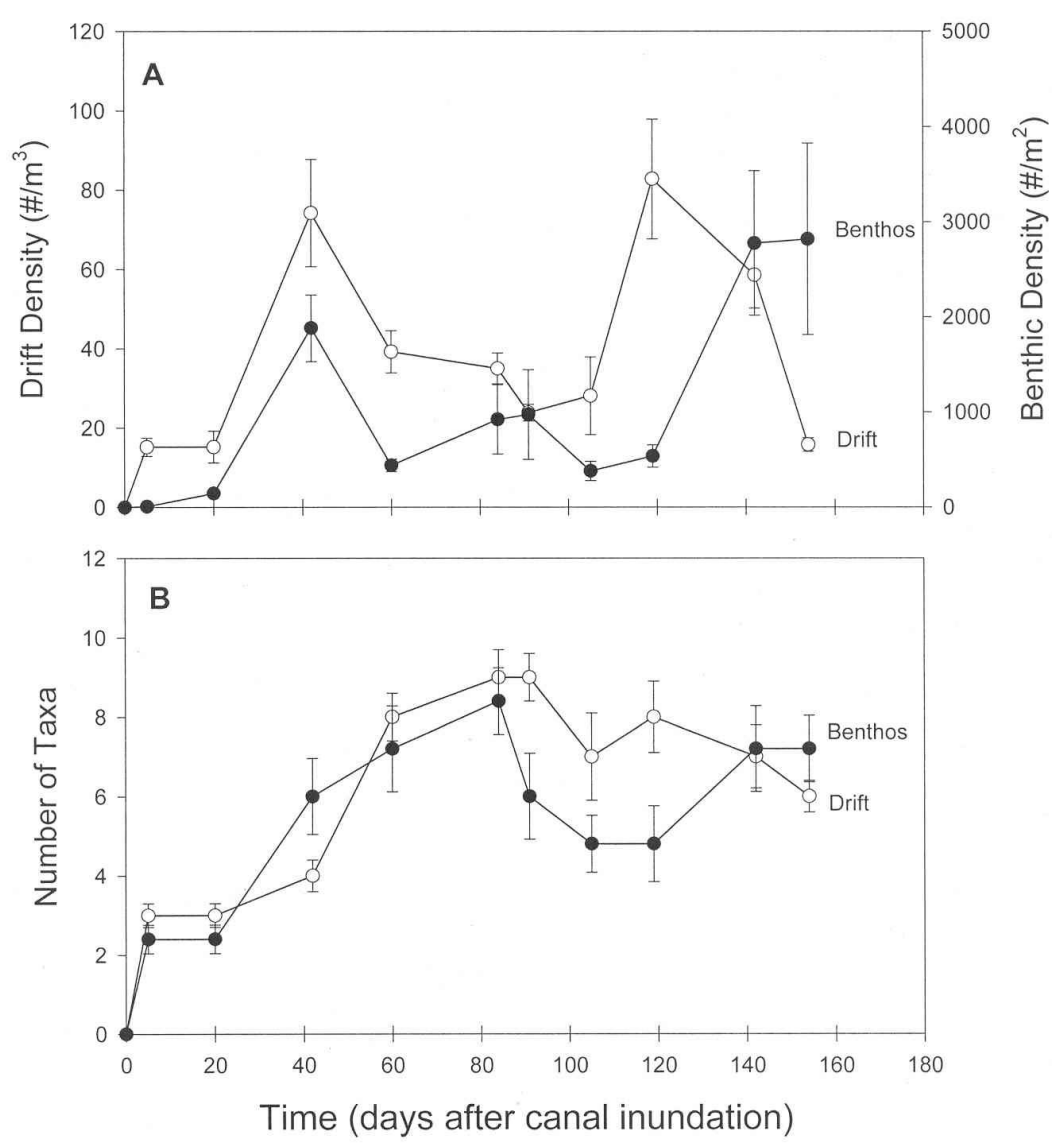

Fig. 3. (A) Mean drift $( \pm 1 \mathrm{SE}, n=15)$ and benthic $( \pm 1 \mathrm{SE}, n=5)$ total densities collected from the canal during the study period. (B) Mean number of taxa collected from the drift $( \pm 1 \mathrm{SE}, n=15)$ and from the benthos $( \pm 1 \mathrm{SE}, n=5)$ during the study.

$1882 \mathrm{~m}^{-2}$ ). In both groups a pulse of chironomid larvae, classified as gathering-collectors, was responsible for this first peak (Fig. 4). A second total density peak occurred on day 119 in the drift $\left(\bar{x}=82 \mathrm{~m}^{-3}, \mathrm{SE} 15.1\right)$ and was mirrored 23 days later by an increase in the benthic total density $\left(\bar{x}=2776 \mathrm{~m}^{-2}\right.$, SE 759$)$. Again, this peak in the drift was due to another pulse in chironomid larvae collected from the water column, though at the same time chironomid numbers in the benthos remained relatively low. However, the following rise in benthic density $\left(\bar{x}=2819 \mathrm{~m}^{-2}\right.$, SE 1007) was the result of a high number of Simulium sp. larvae (filteringcollectors: Fig. 4) collected from the substrate. Densities of Simulium remained high until the canal was drained (15 October: day 174).

Taxonomic composition and relative abundance differed between the benthos and the drift. Drift densities collected at AM, NOON, and PM were not significantly different during each sample date $\left(F_{2,120}=1.2, P>0.05\right)$, so these data were pooled. Although the total density of organisms collected from the benthic substrate $\left(54,430 \mathrm{~m}^{-2}\right)$ was much higher than that from the drift $\left(5795 \mathrm{~m}^{-3}\right)$, a greater number of taxa were collected from the drift (53 taxa) than from the substrate (29 taxa). This result may reflect sampling differences between drift and benthic collections. Drift nets sampled a large portion of the canal's crosssection several times during one 24-h period, whereas benthic collections were made from a relatively small percentage of the overall canal substrate. The most numerically abundant taxa in the drift were chironomid larvae $(73 \%)$ and copepods (12.4\%); Similium sp. and coleopterans (Hydroporus and Agabus) totaled an additional 


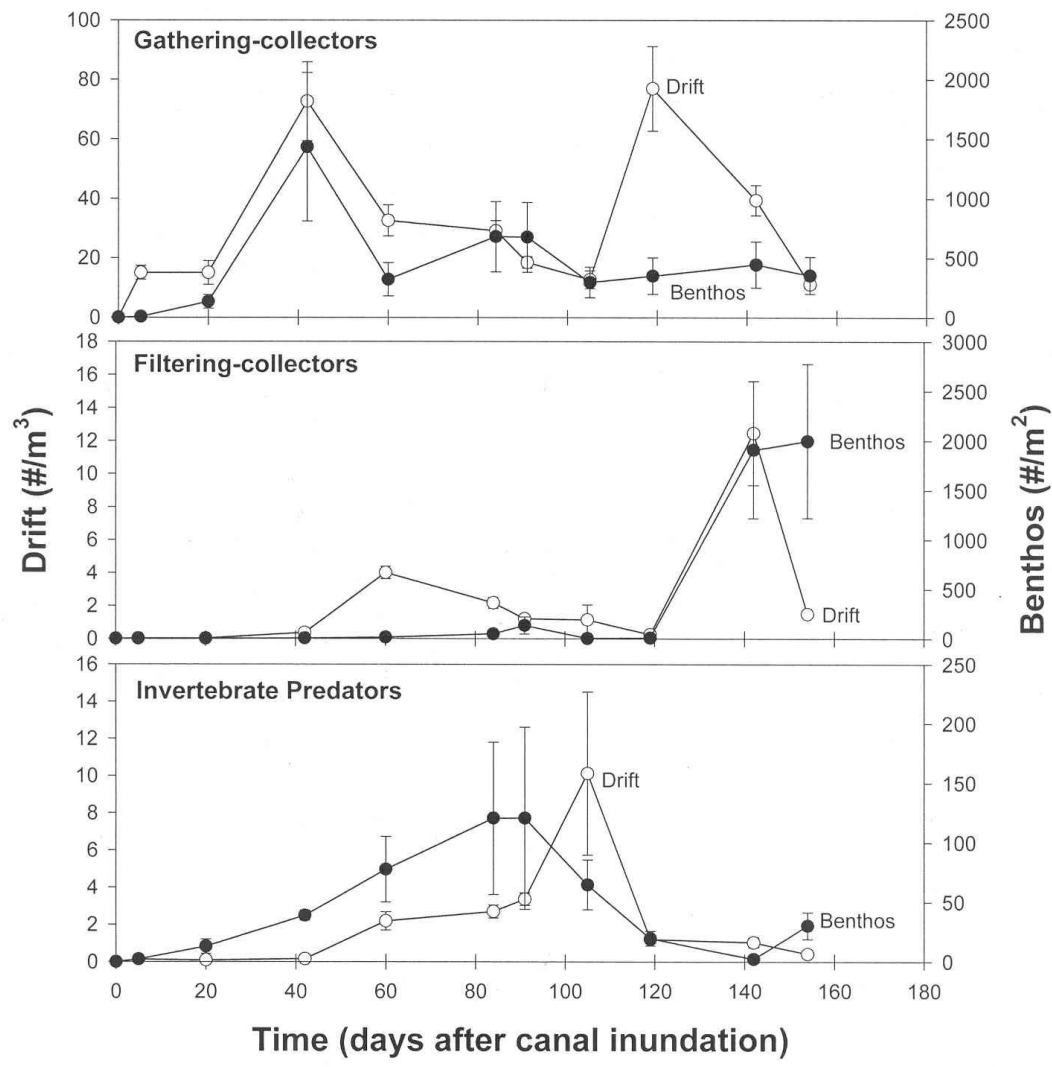

Fig. 4. Mean drift $( \pm 1 \mathrm{SE}, n=15)$ and benthic $( \pm 1 \mathrm{SE}, n=5)$ densities of organisms placed into functional feeding groups collected in the canal during the sampling period. Drift samples taken at different time periods (AM, NOON, PM) are combined.

$6.1 \%$ of drift abundance. Together these 5 taxa composed $91.8 \%$ of all individuals collected in the drift (Table 1). In the benthic substrate, chironomid (39.4\%) and Similium (37.5\%) larvae dominated the benthos in the canal. These 2 taxa, together with Simulium pupae (14.1\%), oligochaetes (1.7\%), Agabus (Coleoptera, 1.7\%), nematodes $(0.8 \%)$ and Oreodytes (Coleoptera, $0.8 \%$ ) composed $96 \%$ of all individuals collected from the canal's substrate (Table 1).

In placing taxa into functional feeding groups (i.e., Cummins and Klug 1979), only 3 groups had high enough densities to analyze. In the drift, gathering-collectors peaked twice throughout the study. Each peak (day $42, \bar{x}=72 \mathrm{~m}^{-3}$, and day $119, \bar{x}=76 \mathrm{~m}^{-3}$ ) was due solely to a large number of chironomid larvae drifting in the water column (Fig. 4). Though a corresponding benthic peak of chironomid larvae occurred on day 42 (mean: 1434 $\mathrm{m}^{-2}$ ), benthic densities of gathering-collectors remained fairly low throughout the remainder of the study. The only filtering-collector sampled in drift was Simulium larvae, and this taxon displayed 2 peaks throughout the study: a minor peak on day $60\left(\bar{x}=4 \mathrm{~m}^{-3}\right)$ and a larger peak on day $142\left(\bar{x}=12.5 \mathrm{~m}^{-3}\right)$. After each peak, Simulium density dropped to just 1-2 individuals $\cdot \mathrm{m}^{-3}$. In the benthos, filteringcollectors were low throughout the study until day 142 when this group had a sharp increase $\left(\bar{x}=1909 \mathrm{~m}^{-2}\right)$ and remained high until the canal was drained in October (Fig. 4). Invertebrate predators in the canal were dominated by coleopterans (beetles). In the substrate, predator density (primarily coleopteran larvae: Agabus, Hydroporus, Oreodytes) increased steadily and peaked on day $91\left(\bar{x}=76.5 \mathrm{~m}^{-2}\right)$ then decreased and remained low throughout the study period. In the drift the predator group, though more diverse (Table 1), displayed the same pattern but lagged behind 
TABLE 1. Functional feeding group (FFG) designation and relative abundance (\%) of organisms collected from the benthic substrate and from the drift in the canal during the study period. $\mathrm{A}=$ adult, $\mathrm{L}=$ larvae, $\mathrm{P}=$ pupae. Total density was measured in number $\cdot \mathrm{m}^{-2}$ for the benthos and number $\cdot \mathrm{m}^{-3}$ for drifting organisms. A value of 0.00 indicated that less than $0.01 \%$ individuals per density unit were collected; horizontal bar indicates that no individuals of that taxa were collected.

\begin{tabular}{|c|c|c|c|}
\hline Taxon & FFG & Benthos & Drift \\
\hline \multicolumn{4}{|l|}{ Amphipoda } \\
\hline Hyalella azteca & Gatherer-collector & 0.4 & 0.19 \\
\hline Bryozoa & & - & 0.00 \\
\hline \multicolumn{4}{|l|}{ Coleoptera } \\
\hline Hydroporus $(\mathrm{L})$ & Predator & 0.7 & 1.52 \\
\hline Agabus (L) & Predator & 1.7 & 1.38 \\
\hline Oreodytes $(\mathrm{L})$ & Predator & 0.8 & 1.09 \\
\hline Laccobius (L) & Predator & 0.1 & 0.06 \\
\hline Haliplus (A) & Shredder-detrivore & - & 0.06 \\
\hline Haliplus (L) & Shredder-detrivore & - & 0.03 \\
\hline Laccophilus (L) & Predator & - & 0.02 \\
\hline Dytiscidae (A) & Predator & - & 0.02 \\
\hline Hydrovatus $(\mathrm{L})$ & Predator & - & 0.01 \\
\hline Brychius (L) & Scraper & - & 0.01 \\
\hline Peltodytes $(\mathrm{L})$ & Shredder-detrivore & - & 0.00 \\
\hline Ochthebius (L) & Predator & - & 0.00 \\
\hline Laccobius (A) & Predator & 0.1 & - \\
\hline Helius & Gather-collector & 0.0 & - \\
\hline \multicolumn{4}{|l|}{ Copepoda } \\
\hline Leptodora kindti & Predator & 0.0 & 0.34 \\
\hline Others & Gatherer-collector & 0.0 & 12.36 \\
\hline \multicolumn{4}{|l|}{ Diptera } \\
\hline Chironomidae (L) & Gatherer-collector & 39.4 & 73.29 \\
\hline Simulium $(\mathrm{L})$ & Filter-collector & 37.5 & 3.20 \\
\hline Chironomidae (P) & & - & 2.64 \\
\hline Culicidae (A) & & - & 0.05 \\
\hline Limnophora & Predator & 0.0 & 0.03 \\
\hline Tabanidae & Predator & - & 0.01 \\
\hline Simulium $(\mathrm{P})$ & & 14.1 & 0.00 \\
\hline Ephydridae (L) & Gather-collector & - & 0.00 \\
\hline Ephydridae $(\mathrm{P})$ & Gather-collector & - & 0.00 \\
\hline Simulium $(\mathrm{A})$ & & - & 0.00 \\
\hline \multicolumn{4}{|l|}{ Ephemeroptera } \\
\hline Calibaetis & Gather-collector & 0.0 & 0.65 \\
\hline Baetis bicaudatus & Gather-collector & 0.1 & 0.39 \\
\hline Baetis tricaudatus & Gather-collector & 0.7 & 0.29 \\
\hline Acentrella & Gather-collector & 0.3 & 0.28 \\
\hline Paraleptophlebia & Gather-collector & 0.4 & 0.04 \\
\hline Attenella & Gather-collector & 0.0 & 0.01 \\
\hline Nixe & Scraper & 0.1 & 0.00 \\
\hline Cinygma & Gather-collector & 0.1 & 0.00 \\
\hline Gastropoda & Scraper & 0.2 & 0.01 \\
\hline \multicolumn{4}{|l|}{ Hemiptera } \\
\hline Sigara & Predator & - & 0.03 \\
\hline Trepobates & Predator & 0.0 & 0.01 \\
\hline Trichocorixa reticulata & Predator & - & 0.00 \\
\hline Cyretes $(\mathrm{L})$ & Predator & 0.0 & - \\
\hline \multicolumn{4}{|l|}{ Hirudinea } \\
\hline Erpobdella & Predator & - & 0.00 \\
\hline Hydracarina & Predator & 0.2 & 0.20 \\
\hline \multicolumn{4}{|l|}{ Hydrozoa } \\
\hline Hydra & Predator & - & 0.03 \\
\hline Bivalvia & Filter-collector & 0.0 & - \\
\hline Nematoda & Predator & 0.8 & 0.12 \\
\hline \multicolumn{4}{|l|}{ Odonata } \\
\hline Libellula & Predator & - & 0.03 \\
\hline Coenagrion & Predator & - & 0.02 \\
\hline Aeshna & Predator & - & 0.00 \\
\hline Oligochaeta & Scraper & 1.7 & 0.15 \\
\hline
\end{tabular}


TABLE 1. Continued.

\begin{tabular}{|c|c|c|c|}
\hline Taxon & FFG & Benthos & Drift \\
\hline \multicolumn{4}{|l|}{ Plecoptera } \\
\hline Capnia & Shredder-detrivore & - & 0.01 \\
\hline \multicolumn{4}{|l|}{ Trichoptera } \\
\hline Hydropsyche & Filter-collector & 0.2 & 0.09 \\
\hline Hydroptila & Scraper & - & 0.06 \\
\hline \multicolumn{4}{|l|}{ Turbellaria } \\
\hline Macrostomum & Predator & 0.1 & 0.01 \\
\hline Hymanella & Predator & - & 0.00 \\
\hline Dugesia tigrina & Predator & - & 0.00 \\
\hline TOTAL DENSITY & & 54,430 & 5795 \\
\hline TOTAL NUMBER OF TAXA & & 29 & 53 \\
\hline
\end{tabular}

the predator benthos by $14 \mathrm{~d}$. Drift predator density peaked on day $105\left(\bar{x}=10.1 \mathrm{~m}^{-3}\right)$, decreased sharply on day $119\left(\bar{x}=1.2 \mathrm{~m}^{-3}\right)$, and remained low for the duration of the study (Fig. 4).

We used polynomial regression to determine whether a density-dependent relationship exists between the benthic invertebrates and those found in the drift. We found no curvilinear response between drift and benthos. The data was best fit by a cubic function; however, the regression model was not significant $\left(F_{3,10}=1.43, P=0.31\right)$.

\section{Discussion}

Although drifting stream invertebrates originate from the benthic substrate, the relationship between drift invertebrates and the benthos remains unclear. Some studies found a densitydependent relationship between drift invertebrates and benthos (Dimond 1967, Anholt 1995, Turner and Williams 2000), while others found the opposite (Hildebrand 1974, Humphries 2002). If the production-compensation hypothesis were true, benthic densities (with little drift) would increase until the carrying capacity of the substrate was reached. At that point, benthic densities would become stable, while drift densities would increase (Waters 1961, 1965). In our study, we found no densitydependent relationship between benthic invertebrates and those in the drift. Over the course of our study period, both drift and benthic densities displayed the same general pattern. We found no evidence that drift density was proportionally greater, at some point, than benthic density.

Why did we not find a density-dependent relationship between drift invertebrates and benthos? First, we examined the entire assemblage of macroinvertebrates, not just several species alone as is commonly done (e.g., Hildebrand 1974, Humphries 2002, Turner and Williams 2000). If drift densities are governed by a behavioral mechanism, then the entire benthic assemblage must be considered, not one or several taxa in isolation. The interaction between predators and prey or between competitors, which may cause some species to enter the drift, does not always occur near or at carrying capacity (necessary for the productioncompensation hypothesis: Allan and Castillo 2007). Further, species prone to drift may be merely exploring the resource potential of a benthic patch before moving on (Mackay 1992). This behavior would have little relationship to benthic densities. Researchers focusing on drift-prone species have found no relationship between drift invertebrates and benthos (e.g., Humphries 2002). Species not prone to drift but found in abundance in the water column would be better candidates to focus on in confirming/rejecting the productioncompensation hypothesis (Waters 1961, 1965). Second, benthic invertebrate densities in our canal system may not have been high enough to reach the carrying capacity of the substrate, resulting in no increase in drift. In most colonization studies, total invertebrate densities level off between 10 and 30 days (Mackay 1992); however, true community equilibrium may not occur until species richness stabilizes (arrival of new species equals the disappearance rate of other species, sensu MacArthur and Wilson 1967). In addition, autumn emergence of adults over the latter part of our study may have reduced benthic densities below carrying capacity so that an increase in drift densities did not occur. Though our benthic density never stabilized (even after $170 \mathrm{~d}$ ), taxon richness did after $84 \mathrm{~d}$. Third, the duration of our study 
may have been too short to allow benthic/ drift relationships to develop. Studies that did not find a density-dependent relationship between benthos and drift invertebrates were conducted over an extremely short time period, usually $1 \mathrm{~d}$ (Hildebrand 1974) to $3 \mathrm{~d}$ (Humphries 2002). Conversely, densitydependent relationships were usually found in studies that were conducted longer than a year (Dimond 1967, Turner and Williams 2000). Our study period was part way between these extremes; thus, benthic community buildup may have not been far enough along to reach carrying capacity or to see a density-dependent relationship.

Finally, we may not have found a relationship between benthic invertebrate densities and drift because our study site may not have been a good mimic of dynamics in a lowland arid stream system. In the summer, small arid streams tend to have low discharge or small pools connected by trickles of water, with "flashy" discharge immediately after rainfall (Poff and Ward 1989). This harsh condition was opposite of the discharge pattern that occurred in our study canal (Fig. 1). During harsh conditions, species both compress their life cycles and leave before conditions deteriorate (Krohne 2001), or they undergo diapause in the substrate and emerge when abiotic conditions improve (Williams 2001).

Are irrigation canals (and other canal types) good proxies for small natural stream systems? In our study, both taxon richness and total benthic density in the canal fell within the range reported for other small streams within $32 \mathrm{~km}$ of our site (Koetsier 2002). Likewise, benthic community development in the canal was consistent with lotic invertebrate colonization dynamics reported in the literature. Stream invertebrates begin to appear on bare substrate within $24 \mathrm{~h}$. Further, these colonists tend to be species that are prone to drift: baetid mayflies, Simulium larvae, and chironomid larvae (Mackay 1992). In our study, chironomid and Simulium larvae were the first organisms found in the drift and substrate. In addition, predators appeared later once prey populations had been established, following the predicted development sequence in a natural stream (Peckarsky 1986). Shreddingdetrivore insects are the last to colonize, provided there is adequate leaf detritus available. This group usually has poor dispersal ability and relies on seasonal leaf fall (Mackay 1992). Our system lacked leaf litter, so shreddingdetrivores occurred in very low numbers.

Finding no diel drift periodicity by macroinvertebrates in the canal was unexpected but not surprising. Others have reported an aperiodic drift pattern in small streams lacking fish predators (Turcotte and Harper 1982, Flecker 1992) and by small bodied invertebrates (i.e., chironomids, Simulium larvae) in streams with fish (Allan 1978, Skinner 1985). Some researchers suggest that drift periodicity may be a response by the macroinvertebrates to visually oriented predators (Müller 1974, Allan 1978, Brittain and Eikeland 1988). With no fish in our study canal, invertebrates may have utilized all portions of the substrate without risk of vertebrate predation leading to aperiodic drift.

While the macroinvertebrate assemblage in the canal appeared similar to that in nearby natural streams and what is reported in the literature, the algal and biofilm dynamics were not. Overall, algal and biofilm biomass in the canal fell within the range sampled in nearby streams (Koetsier 2002); however, it was much more variable over time. Further, Osborne (1983) found that in an ungrazed community, maximum primary productivity had been attained within $21 \mathrm{~d}$. Though we did not measure primary production, our algal and biofilm measurements indicated that the algal community did not stabilize until day 105 (Fig. 2).

In most respects, the canal we studied provided a reasonable representation of macroinvertebrate community development in a small stream ecosystem. However, the canal did differ from a small arid stream in flow timing and variability. Because discharge (along with dissolved oxygen and temperature) in the canal is constant during the summer, the canal may provide a potential refuge for aquatic invertebrates during arid summertime conditions.

In the United States, canals have been understudied and their effects on aquatic and terrestrial organisms and nonagriculture services (e.g., uptake/release of nutrients, decomposition of organic matter) are largely unknown (Herzon and Helenius 2008, Roach et al. 2008, Simon and Travis 2011). In addition, irrigation canals have become a dominant aquatic feature in the arid West and now provide new habitat and increased habitat heterogeneity for fish (Mueller and Liston 1994, Cowley et 
al. 2007) and invertebrates (Marsh and Stinemetz 1983, Simon and Travis 2011). Further, canals also may act as "pathways," allowing invasive species to colonize new water bodies and expand their range (Marsh 1985, Bij de Vaate et al. 2002, Urquhart and Koetsier 2014). Smaller canals could be used as ecological mesocosms for short-term manipulative experiments exploring questions in macroinvertebrate and fish ecology. However, care must be taken in extrapolating findings from canals to natural stream systems, especially in arid environments. Because of physiochemical differences in seasonal timing and constancy, some canals may represent a totally new, temporary habitat with a unique ecology, warranting further study.

\section{Literature Cited}

Allan, J.D. 1978. Trout predation and the composition of stream drift. Limnology and Oceanography 23: 1231-1237.

Allan, J.D., AND M.M. Castillo. 2007. Stream ecology: structure and function of running waters. 2nd edition. Springer, Dordrecht, The Netherlands. dx.doi.org/ 10.1007/978-1-4020-5583-6

Anholt, B.R. 1995. Density dependence resolves the stream drift paradox. Ecology 76:2235-2239.

Barbour, M.T., J. Geritsen, B.D. SNyder, and J.B. STRIBLING. 1999. Rapid bioassessment protocols for use in streams and wadeable rivers: periphyton, benthic macroinvertebrates and fish. 2nd edition. EPA 841-B-99-002, U.S. Environmental Protection Agency, Office of Water, Washington, DC.

Bij de Vaate, A., K. Jazdezewski, H.A.M. Ketelaars, S. GOLLASCH, AND G. VANDER VELDE. 2002. Geographical patterns in range extension of Ponto-Caspian macroinvertbrate species in Europe. Canadian Journal of Fisheries and Aquatic Sciences 59:1159-1174.

BRITTAIN, J.E., AND T.J. EIKELAND. 1988. Invertebrate drifta review. Hydrobiologia 166:77-93.

Cowley, D.E., R.C. Wissmar, and R. Sallenave. 2007. Fish assemblages and seasonal movements of fish in irrigation canals and river reaches of the middle Rio Grande, New Mexico (USA). Ecology of Freshwater Fish 16:548-558.

Cummins, K.W., and M.J. KLug. 1979. Feeding ecology of stream invertebrates. Annual Review of Ecology and Systematics 10:147-172.

DenbY, J.S. 1944. The fate of animals in stream drift when carried into lakes. Ecological Monographs 16:321-335.

Dimond, J.B. 1967. Evidence that drift of stream benthos is density related. Ecology 48:855-857.

FIEGE, M. 1999. Irrigated Eden: the making of an agricultural landscape in the American West. University of Washington Press, Seattle, WA.

FLECKER, A.S. 1992. Fish predation and the evolution of invertebrate drift periodicity: evidence from $\mathrm{Neo}-$ tropical streams. Ecology 73:438-448.

Gibbins, C., D. Veriat, and R.J. Batalla. 2007. When is stream invertebrate drift catastrophic? The role of hydraulics and sediments transport in initiation drift during flood events. Freshwater Biology 52: 2369-2384.

Gordon, N.D., T.A. McMahon, B.L. Finlayson, C.J. GipPEL, AND R.J. NATHan. 2004. Stream hydrology: an introduction for ecologists. 2nd edition. John Wiley \& Sons, Ltd., West Sussex, England.

Gore, J.A. 1979. Patterns of initial benthic recolonization of a reclaimed coal strip-mined river channel. Canadian Journal of Zoology 57:2429-2439.

Hansson, L.A. 1988. Chlorophyll a determination of periphyton on sediments: identification of problems and recommendation of methods. Freshwater Biology $20: 347-352$

Herzon, I., AND J. Helenius. 2008. Agricultural drainage ditches, their biological importance and functioning. Biological Conservation 141:1171-1183.

Holm-Hansen, O. 1978. Chlorophyll a determination: improvements in methodology. Oikos 30:438-447.

Hildebrand, S.G. 1974. The relation of drift to benthos and food level in an artificial stream. Limnology and Oceanography 19:951-957.

Humphries, S. 2002. Dispersal in drift-prone macroinvertebrates: a case for density-independence. Freshwater Biology 47:921-929.

Imbert, J.B., And J.A. Perry. 2000. Drift and benthic invertebrate responses to stepwise and abrupt increases in non-scouring flow. Hydrobiologia 436: 191-208.

Koetsier, P. 2002. Short term benthic colonization dynamics in an agricultural stream recovering from slaughterhouse effluents. Journal of the American Water Resources Association 38:1409-1422.

Koetsier, P. 2005. Response of a stream diatom community to top predator manipulations. Aquatic Sciences 67:517-527.

KoHLER, S.L. 1985. Identification of stream drift mechanisms: an experimental and observational approach. Ecology 66:1749-1761.

Krohne, D.T. 2001. General ecology. 2nd edition. Brooks/ Cole Publishing, Pacific Grove, CA.

Leslie, A.W., R.F. Smith, D.E. Ruppert, K. Bejleri, J.M. McGrath, B.A. NeEdelman, and W.O. Lamp. 2012. Environmental factors structuring benthic macroinvertebrate communities of agricultural ditches in Maryland. Environmental Entomology 41:802-812.

MacArthur, R.H., and E.O. WiLson. 1967. The theory of island biogeography. Monographs in Population Biology 1, Princeton University Press, Princeton, NJ.

MACKAY, R.J. 1992. Colonization by lotic macroinvertebrates: a review of processes and patterns. Canadian Journal of Fisheries and Aquatic Sciences 49: 617-628.

MaRsh, P.C. 1985. Secondary production of introduced Asiatic clam, Corbicula fluminea, in a central Arizona canal. Hydrobiologia 124:103-110.

Marsh, P.C., AND C.R. StinemetZ. 1983. Benthic invertebrates of the earthen Coachella Canal, California. California Fish and Game 69:77-83.

Merritt, R.W., K.W. Cummins, and M.B. Berg. 2008. An introduction to the aquatic insects of North America. 4th edition. Kendall/Hunt Publishing Company, Dubuque, IA

Mueller, G., AND C.R. Liston. 1994. Evaluation of tire reefs for enhancing aquatic communities in concretelined canals. North American Journal of Fisheries Management 14:616-625. 
MüLleR, K. 1974. Stream drift as a chronobiological phenomenon in running water ecosystems. Annual Review of Ecology and Systematics 5:309-323.

Osborne, L.L. 1983. Colonization and recovery of lotic epilithic communities: a metabolic approach. Hydrobiologia 99:29-36.

Peckarsky, B.L. 1986. Colonization of natural substrates by stream benthos. Canadian Journal of Fisheries and Aquatic Sciences 43:700-709.

PennaK, R.W. 1989. Fresh-water invertebrates of the United States. 3rd edition. John Wiley \& Sons, Inc., NY.

POFF, N.L., AND J.V. WARD. 1989. Implications of streamflow variability and predictability for lotic community structure: a regional analysis of streamflow patterns. Canadian Journal of Fisheries and Aquatic Sciences 46:1805-1818.

Roach, W.J., J.B. Heffernan, N.B. Grimm, J.R. ArrowSMith, C. Eisinger, and T. RYCHENER. 2008. Unintended consequences of urbanization for aquatic ecosystems: a case study from the Arizona desert. BioScience 58:715-727.

SimON, T.N., AND J. Travis. 2011. The contribution of manmade ditches to the regional stream biodiversity of the new river watershed in the Florida panhandle. Hydrobiologia 661:163-177.

SKInNER, W.D. 1985. Night-day drift patterns and the size of larvae of two aquatic insects. Hydrobiologia 124: $283-285$

Steinman, A.D., G.A. Lamberti, and P.R. LeavitT. 2006 Biomass and pigments of benthic algae. Pages 357-380 in F.R. Hauer and G.A. Lamberti, editors, Methods in stream ecology. 2nd edition. Academic Press, NY.

Turcotte, P., AND P.P. Harper. 1982. Drift patterns in a high Andean stream. Hydrobiologia 89:141-151.
Turner, D., And D.D. Williams. 2000. Invertebrate movements within a small stream: density dependence or compensating for drift? International Reviews of Hydrobiology 85:141-156.

Urquhart, A.N., And P. Koetsier. 2014. Diet of a cryptic but widespread invader, the oriental weatherfish (Misgurnus anguillicaudatus) in Idaho, USA. Western North American Naturalist 74:92-98.

Williams, D.D. 1977. Movements of benthos during the recolonization of temporary streams. Oikos 29: 306-312.

Williams, D.D. 2001. The ecology of temporary waters. Blackburn Press, Caldwell, NJ.

Williams, D.D., AND H.B.N. Hynes. 1977. Benthic community development in a new stream. Canadian Journal of Zoology 55:1071-1076.

Williams, P.C., M. Whitfield, J. Biggs, S. Bray, G. Fox, P. Nicolet, AND D. SEAR. 2004. Comparative biodiversity of rivers, streams, ditches, and ponds in an agricultural landscape in Southern England. Biological Conservation 115:329-341.

WATERS, T.F. 1961. Standing crop and drift of stream bottom organisms. Ecology 42:532-537.

WATERS, T.F. 1965. Interpretation of invertebrate drift in streams. Ecology 46:327-334.

Waters, T.F. 1972. The drift of stream insects. Annual Review of Entomology 17:253-272.

Waters, T.F. 2000. Wildstream: a natural history of the free flowing river. Riparian Press, St. Paul, MN.

Received 30 September 2014 Accepted 7 April 2015 